\title{
Biological control of Pectobacterium carotovorum subsp. carotovorum, the causal agent of bacterial soft rot in vegetables, in vitro and in vivo tests
}

\author{
Hassan Abd-El-Khair ${ }^{1}$, Tarek G. Abdel-Gaied ${ }^{1 *}$, Maurice S. Mikhail², Ahmed I. Abdel-Alim² \\ and Hamdy I. Seif El-Nasr ${ }^{1}$
}

\begin{abstract}
Background: Several chemical bactericides were applied for controlling soft rot bacteria, Pectobacterium carotovorum subsp. carotovorum, which causes the destructive soft rot disease to many economically important vegetables, but because of their toxic hazards on human and environment became limit. The biocontrol was applied to control many plant pathogens. Therefore, this work is aimed to study the antagonistic activity of bacterial agents, i.e. Bacillus subtilis, Bacillus pumilus, Bacillus megaterium and Pseudomonas fluorescens, and fugal agents, i.e. Trichoderma harzianum, Trichoderma viride and Trichoderma virens, to control bacterial soft rot disease under in vitro and in vivo tests.

Results: The tested treatments could protect the potato tubers against the development of soft rot. T. viride and T. virens were highly effective in reducing soft rot symptoms on inoculated potato tuber slices, when applied at the same time or $2 \mathrm{~h}$ before pathogen inoculation, while B. megaterium and T. harzianum were highly effective when applied at the same time or $2 \mathrm{~h}$ after pathogen inoculation. In whole potato tubers technique, B.pumilus highly protected the stored potato tuber under artificially infection conditions, than P. fluorescens, T. harzianum, B. subtilis, T. viride, T. virens and B. megaterium, respectively.

Conclusion: Application of fungal agents or specify the bacterial species can play an important role in controlling bacterial soft rot disease in vegetables and increase the stored periods of potato tubers under storage conditions without any toxic effects.
\end{abstract}

Keywords: Biological control, Pectobacterium carotovorum, Soft rot disease, Vegetables

\section{Background}

Pectobacterium carotovorum subsp. carotovorum (Syn. Erwinia carotovora subsp. carotovora) causes the destructive soft rot disease to many economically important vegetables such as carrot, cabbage, cucumber, eggplant, garlic, onion, pepper, potato, radish, sweet potato, squash and tomato (Opara and Asuquo 2016), where the

\footnotetext{
*Correspondence: tgommaa@yahoo.com

${ }^{1}$ Plant Pathology Department, National Research Centre, Dokki, Giza, Egypt

Full list of author information is available at the end of the article
}

disease can be detected in the field, transmit, storage and market. The soft rot bacteria can successfully penetrate the plant, through the wounds or natural openings, causing economic damage to fleshy vegetables by producing many cell wall-degrading enzymes (Péromblon 2002; Bhat et al. 2010). Application of chemical bactericides for controlling soft rot bacteria is not favored because of their non-persistence, side toxic effects, high cost as well as development of resistance in bacterial populations (Jones et al. 1996; Vanneste 2000).

Therefore, biological control may be one of the good crop protection methods for controlling bacterial soft 
rot disease by application of Trichoderma spp., Bacillus spp. or Pseudomonas spp. which widely applied as biological agents against many soil-borne pathogens (Wulff et al. 2003; Alabouvette et al. 2006). Applications of $B$. cereus, B. subtilis, B. megaterium or B. pumilus showed good activity against $P$. carotovorum subsp. carotovorum in vitro tests using the disk plate method (Issazadeh et al. 2012). Pseudomonas spp. also controlled the bacterial soft rot disease in Valerian rhizome as well as significantly increased the fresh and dry weights of root (Ghods-Alavi et al. 2012). When neem cake applied in soil with $P$. putida as seeds treatment, it could reduce $E$. carotovora infection as well as significantly increased the carrot yield under field conditions (Sowmya et al. 2012). Pseudomonas fluorescens and B. subtilis showed the highest inhibitory effects against $E$. carotovora subsp. carotovora in vitro and in the pot experiment (Algeblawi and Adam 2013). Bacillus spp. and B. pumilus controlled $P$. carotovorum subsp. carotovorum in chili in vivo, where all treatments showed a higher reduction in disease severity than the controls (Silva et al. 2014). Trichoderma asperellum also could reduce the pathogenic effect of $E$. carotovora on the young seedlings of okra (Idowu et al. 2016).

Therefore, this work aimed to test seven biocontrol agents, i.e. four bacterial agents, namely B. subtilis, $B$. pumilus, B. megaterium and $P$. fluorescens, and three fungal agents, namely T. harzianum, T.viride and T. virens, to control $P$. carotovorum subsp. carotovorum in vitro and in vivo tests.

\section{Methods}

\section{Soft rot pathogen}

Fifteen bacterial soft rot strains isolated from some vegetables showing naturally typical bacterial soft rot symptoms were collected from some marketing and storage locations in Egypt (Table 1). All bacterial strains were identified as P.carotovorum subsp. carotovorum according to pathological, cultural, morphological and biochemical characters using standard bacteriological methods in pervious study by Mikhail et al. (2019).

\section{Preparation of soft rot bacteria inoculum}

The bacterial inoculums of soft rot bacterial strains were prepared by growing of each bacterial strain on nutrient glucose $(2 \%)$ agar medium in slant tubes. All inoculated slants were incubated at $28{ }^{\circ} \mathrm{C} \pm 2$ for $48 \mathrm{~h}$. The bacterial suspension for each strain was done by scraping the bacterial growth in $5 \mathrm{ml}$ of sterile $0.2 \mathrm{M}$ phosphate buffer ( $\mathrm{pH}$ 7.2). The bacterial inoculums were adjusted to a standard inoculums density [ca. $10^{7-9}$ colony forming unit $(\mathrm{CFU}) / \mathrm{ml}$ ] by measuring the turbidity using a Prim
Table 1 Soft rot bacteria strains isolated from some vegetables

\begin{tabular}{lll}
\hline Strains code & Vegetables & Soften plant parts \\
\hline$P C C_{1}$ & potato (Solanum tuberosum L.) & Tubers \\
$P C C_{2}$ & & \\
$P C C_{3}$ & & \\
$P C C_{4}$ & & \\
$P C C_{5}$ & Sweet potato (Ipomoea batatas L.) & Roots \\
$P C C_{6}$ & Cucumber (Cucumis sativus L.) & Fruits \\
$P C C_{7}$ & & \\
$P C C_{8}$ & & \\
$P C C_{9}$ & Carrot (Daucus carotovora L.) & Roots \\
$P C C_{10}$ & \\
$P C C_{11}$ & & \\
$P C C_{12}$ & Eggplant (Solanum melongena L.) & Fruits \\
$P C C_{13}$ & & \\
$P C C_{14}$ & Chili (Capsicum frutescens L.) & Fruits \\
$P C C_{15}$ & & \\
\hline
\end{tabular}

light spectrophotometer at $610 \mathrm{~nm}$ and then kept at cool conditions until used within $12 \mathrm{~h}$ (Moh et al. 2012).

\section{Biocontrol agents}

Four bacterial agents namely $B$. subtilis, B. pumilus, $B$. megaterium and $P$. fluorescens, and three fungal agents namely $T$. harzianum, $T$. viride and $T$. virens, were tested in this work. All biocontrol agents were obtained from Plant Pathology Department, National Research Centre.

\section{Preparation of the biocontrol agents}

Preparation of cultural filtrates of each bacterial biocontrol agent was carried out using sterilized nutrient glucose (2\%) broth medium ( $3 \mathrm{~g}$ beef extract, $5 \mathrm{~g}$ peptone, $20 \mathrm{~g}$ glucose in one liter distilled water, $\mathrm{pH}$ 7.2) in $250 \mathrm{ml}$ flasks. Each flask was separately inoculated with $1 \mathrm{ml}$ of 48-h-old-culture of each bacterial agent. Three flasks were used as replicates for each bacterial antagonist. The inoculated flasks were incubated at $28 \pm 2{ }^{\circ} \mathrm{C}$ for $48 \mathrm{~h}$ under static conditions. Each bacterial culture was centrifugated at $2038 \times \mathrm{g}$ for $15 \mathrm{~min}$; then, the supernatant was filtered through filter paper (Whatman No.1) and finally sterilized by filtration through sterile $0.45 \mu \mathrm{m}$ membrane filter (cellulose nitrate, Whatman). The bacterial filtrates were then kept at $-20^{\circ} \mathrm{C}$ until used (Abd-ElKhair and Haggag 2007).

Preparation of cultural filtrates of each Trichoderma spp. was made using sterilized potato glucose $2 \%$ broth medium ( $200 \mathrm{ml}$ potato extract and $20 \mathrm{~g}$ glucose in one liter distilled water) in $250 \mathrm{ml}$ flasks. Each flask was separately inoculated with $1 \mathrm{~cm}$-diameter disc of one-weekold culture of each Trichoderma spp. The inoculated 
flasks were incubated at $28 \pm 2{ }^{\circ} \mathrm{C}$ for one week under static conditions. Then, the Trichoderma spp. mycelial mats were separated by filtration with filter paper (Whatman No.1) and finally the fungal cultural filtrates were sterilized by filtration through sterile $0.45 \mu \mathrm{m}$ membrane filter. The fungal cultural filtrate of each Trichoderma spp. was separately kept at $-20{ }^{\circ} \mathrm{C}$ until used (Abd-ElKhair and Haggag 2007).

\section{Screening for antagonistic activity in vitro tests}

The inhibitory activity of cultural filtrates of biocontrol agents against all P.carotovorum subsp. carotovorum strains were tested by using filter paper disc plate method (Thornberry 1950). All tests were laid in complete randomized design with four replicates. Twenty milliliters of nutrient glucose $(2 \%)$ agar medium were poured in each sterile Petri dish $(9 \mathrm{~cm}$-diameter) and allowed to solidify. Each Petri dish was separately inoculated with $0.1 \mathrm{ml}$ of each soft rot bacterial strain suspension $\left(10^{7-9} \mathrm{CFU} / \mathrm{ml}\right)$ onto the surface of the plate in the center by pipette. The bacterial inoculums were spread over the surface of the plate using a sterile L-shaped spatula and let for $5 \mathrm{~min}$. The filter paper discs ( $5 \mathrm{~mm}$-diameter) were immersed individually for $1 \mathrm{~min}$ in each cultural filtrate of biocontrol agent which prepared before. For control, the filter paper discs were soaked in sterilized distilled water. Four filter paper discs were used as replicates for each treatment as well as the controls. The inoculated Petri dishes were incubated at $28 \pm 2{ }^{\circ} \mathrm{C}$ for $48 \mathrm{~h}$. The antibacterial activity was recorded by measuring the diameter of the zones of inhibition around the filter paper disc (Mills et al. 2006; Rashid et al. 2013).

\section{Screening for antagonistic activity in vivo tests \\ a. Potato slices method}

The inhibitory activity of cultural filtrates of applied biocontrol agents, against high pathogenic P.carotovorum subsp. carotovorum strains, i.e. $P c_{3}, P c_{4}$ and $P c c_{5}$, were tested by using potato tuber slices method. Healthy potato tubers cv. Diamond was surface-sterilized by sodium hypochlorite solution at concentration of $5 \%$ for $3 \mathrm{~min}$. The potato tubers were washed in serial of sterile distilled water and left for drying. The potato tubers were cut into slices $(2 \mathrm{~cm}$-thick) by sterile knife under sterile conditions. One potato slice was put in each Petri dish containing sterilized filter paper and impregnated with $3 \mathrm{ml}$ of sterile distilled water. Then, each potato slice was separately inoculated with $0.1 \mathrm{ml}$ of each soft rot bacteria suspension onto the center. Each cultural filtrate of biocontrol agent was applied at the same time of pathogen inoculation and $2 \mathrm{~h}$ before or after pathogen inoculation. Potato slices were separately treated with pathogenic bacteria suspension and distilled water for controls. Three potato slices were used as replicates for each treatment. Inoculated potato slices were incubated at $30{ }^{\circ} \mathrm{C} \pm 2$ for $72 \mathrm{~h}$. The soft rot symptoms were evaluated according to the scale described by Bartz (1999), as the following:no rotting; + restricted $\operatorname{rot}<1 \mathrm{~cm} ;++$ small active rot $1-2 \mathrm{~cm}$ and +++ highly active $\mathrm{rot}>2 \mathrm{~cm}$.

\section{b. Potato tubers method}

The inhibitory activity of cultural filtrates of applied biocontrol agents against the highest pathogenic $P$. carotovorum subsp. carotovorum ( $P c c_{3}$ strain) were tested by using potato tubers method. Healthy potato tubers $\mathrm{cv}$. Diamond were surface sterilized by sodium hypochlorite solution as mentioned before. Then, each potato tuber was wounded in three places using sterile knife (cross hale). Firstly, potato tubers were separately treated with each cultural filtrate by spraying with atomizer and then allowed $2 \mathrm{~h}$ for drying. Then, the treated tubers were inoculated with bacterial pathogen inoculums by spraying with atomizer and then air-dried. For controls, potato tubers were either treated with bacterial pathogen inoculums or distilled water. Ten inoculated potato tubers were weighed and stored in plastic net at room temperature. Three batches were employed as replicates for each treatment as well as the controls. Data of soft rot incidence were weekly recorded for 3 months. Weight of soft rot infected tubers were recorded and expressed in percentage using the following modified formula described by Abd-El-Khair and Haggag (2007).

$$
\begin{aligned}
& \text { Soft rot incidence } \% \\
& =\frac{\text { Initial weight of tubers }- \text { Weight of healthy tubers }}{\text { Initial weight of tubers }} \\
& \quad \times 100
\end{aligned}
$$

\section{Statistical analysis}

Data were subjected to analysis of variance using Computer Statistical Package (CO-STATE) version 3.03, Barkley Co., USA, and means were compared using the Least Significant Difference (LSD) test at $P=0.05$ (Snedecor and Cochran 1980). The significance of the treatment effects, concentration, exposure time and their interactions were also analyzed.

\section{Results}

\section{In vitro tests}

The cultural filtrates of each $B$. subtilis, B. pumilus, $B$. megaterium and $P$. fluorescens could inhibit the bacterial growth of all tested $P$. carotovorum subsp. carotovorum strains, except $P c c_{6} \& P c c_{8}$ strains and $P c c_{9} \& P c c_{10}$ strains, which isolated from cucumber fruits and carrot roots, respectively (Table 2). The cultural filtrates of 
Table 2 Inhibitory activity of the crude cultural filtrates of bacterial agents against the bacterial growth of Pectobacterium carotovorum subsp. carotovorum strains in vitro tests

\begin{tabular}{|c|c|c|c|c|c|}
\hline \multirow[t]{2}{*}{ P. c. subsp. carotovorum } & \multicolumn{5}{|c|}{ Inhibition zone $(\mathrm{cm})$ of bacterial growth } \\
\hline & Control & Bacillus subtilis & Bacillus pumilus & Bacillus megaterium & $\begin{array}{l}\text { Psudomonas } \\
\text { fluorescens }\end{array}$ \\
\hline \multicolumn{6}{|l|}{ Potato strains } \\
\hline$P C C_{1}$ & 0.00 & 0.90 & 0.95 & 0.73 & 0.70 \\
\hline $\mathrm{PCC}_{2}$ & 0.00 & 0.91 & 0.96 & 0.00 & 0.00 \\
\hline $\mathrm{PCC}_{3}$ & 0.00 & 0.95 & 0.73 & 0.86 & 0.85 \\
\hline $\mathrm{PCC}_{4}$ & 0.00 & 0.88 & 0.71 & 0.70 & 0.81 \\
\hline \multicolumn{6}{|l|}{ Sweet potato strain } \\
\hline $\mathrm{PCC}_{5}$ & 0.00 & 0.68 & 0.70 & 0.70 & 0.70 \\
\hline \multicolumn{6}{|l|}{ Cucumber strains } \\
\hline$P_{C C_{6}}$ & 0.00 & 0.00 & 0.00 & 0.00 & 0.00 \\
\hline $\mathrm{PCC}_{7}$ & 0.00 & 0.70 & 0.70 & 0.65 & 0.68 \\
\hline $\mathrm{PCC}_{8}$ & 0.00 & 0.00 & 0.00 & 0.00 & 0.00 \\
\hline \multicolumn{6}{|l|}{ Carrot strains } \\
\hline$P C C_{9}$ & 0.00 & 0.00 & 0.00 & 0.00 & 0.00 \\
\hline$P C C_{10}$ & 0.00 & 0.00 & 0.00 & 0.00 & 0.00 \\
\hline$P C C_{11}$ & 0.00 & 0.81 & 0.68 & 1.00 & 0.70 \\
\hline \multicolumn{6}{|l|}{ Eggplants strains } \\
\hline$P C C_{12}$ & 0.00 & 0.66 & 0.73 & 0.71 & 0.00 \\
\hline$P C C_{13}$ & 0.00 & 0.00 & 0.70 & 0.00 & 0.00 \\
\hline \multicolumn{6}{|l|}{ Chili fruits strains } \\
\hline$P C C_{14}$ & 0.00 & 0.78 & 0.85 & 0.85 & 0.78 \\
\hline$P C C_{15}$ & 0.00 & 0.70 & 0.71 & 0.66 & 0.71 \\
\hline Total mean & & 0.53 & 0.56 & 0.46 & 0.40 \\
\hline
\end{tabular}

L.S.D. 0.05 Strains $(I)=0.02$ Bioagent $(B)=0.021 \times B=0.11$

above bacterial biocontrol agents inhibited the bacterial growth of $P$. carotovorum subsp. carotovorum in the ranges of $0.66-0.95 \mathrm{~cm}, 0.68-0.96 \mathrm{~cm}, 0.65$ to $1.00 \mathrm{~cm}$ and $0.68-0.85 \mathrm{~cm}$, respectively (Table 2). Results revealed that strain $P c c_{3}$ showed the highest inhibition by the cultural filtrates of B. subtilis, followed by $P c c_{2}, P c c_{1}, P c c_{4}$, $P c c_{11}, P c c_{14}, P c c_{7}, P c c_{15}, P c c_{5}$ and $P c c_{12}$, respectively. Strain $P c c_{3}$ also was highly affected the cultural filtrates of $P$. fluorescens, followed by $P c c_{4}, P c c_{14}, P c c_{15}, P c c_{1}, P c c_{5}$, $P c_{11}$ and $P c_{7}$, respectively. Results showed that strain $P c c_{2}$ was highly inhibited by the cultural filtrates of $B$. pumilus, followed by $P c c_{1}, P c c_{14}, P c c_{3}, P c c_{12}, P c c_{4}, P c c_{15}$, $P c c_{5}, P c c_{7}, P c c_{13}$ and $P c c_{11}$, respectively, while strain $P c c_{11}$ was highly inhibited by the cultural filtrates of $B$. megaterium, followed by $P c c_{3}, P c c_{14} P c c_{1}, P c c_{12}, P c c_{4}, P c c_{5}, P c c_{15}$ and $P c_{7}$, respectively (Table 2).

Results revealed that the cultural filtrates of fungal agents, i.e., T. harzianum, T. viride and T. virens, could inhibit the bacterial growth of all tested $P$. carotovorum subsp. carotovorum strains, except $P c c_{6}$ and $P c c_{10}$ isolated from cucumber and carrot rots, receptively. The above Trichoderma spp. inhibited the bacterial growth of soft rot bacteria strains in the ranges of $0.66-1.08 \mathrm{~cm}, 0.70-$ 0.93 and $0.70-1.1 .10 \mathrm{~cm}$, respectively (Table 3 ). $T$. harzianum was the most effective against strain $P c c_{8}$, followed by $P c c_{2}, P c c_{11}, P c c_{1}, P c c_{4}, P c c_{5}, P c c_{7}, P c c_{3}, P c c_{13}, P c c_{14}$ and $P c c_{15}$, respectively. T. viride was the most effective against strain $P c c_{15}$, followed by $P c c_{11}, P c_{14}, P c c_{8}, P c c_{7}, P c c_{3}$, $P c c_{5}, P c c_{4}$ and $P c c_{12}$, respectively. Results showed that $T$. virens was the most effective against strain $P c c_{8}$, followed by $P c c_{1}, P c c_{11}, P c c_{2}, P c c_{4}, P c c_{14}, P c c_{15}, P c c_{5}, P c c_{3}, P c c_{7}$ and $P c c_{9}$, respectively (Table 3 ).

\section{In vivo tests}

\section{a. Potato tuber slices method}

Results showed that the cultural filtrates of B. subtilis, B. pumilus, B. megaterium, P. fluorescens, T. harzianum, $T$. viride and $T$. virens could reduce the incidence of soft rot disease on potato slices when inoculated with pathogenic strains, viz. $P c c_{3}, P c c_{4}$ and $P c c_{5}$, at the same time of inoculation and $2 \mathrm{~h}$ before or after inoculation (Table 4). Results showed that B. subtilis when applied at $2 \mathrm{~h}$ before the bacterial pathogen inoculation (strains $P c c_{4}$ and $P c c_{5)}$ produced highly active rot symptoms on 
Table 3 Inhibitory activity of the crude cultural filtrates of fungal agents against the bacterial growth of Pectobacterium carotovorum subsp. carotovorum strains in vitro tests

\begin{tabular}{|c|c|c|c|c|}
\hline \multirow{2}{*}{$\begin{array}{l}\text { P.c. subsp. } \\
\text { carotovorum }\end{array}$} & \multicolumn{4}{|c|}{ Inhibition zone $(\mathrm{cm})$ of bacterial growth } \\
\hline & Control & $\begin{array}{l}\text { Trichoderma } \\
\text { harzianum }\end{array}$ & $\begin{array}{l}\text { Trichoderma } \\
\text { viride }\end{array}$ & $\begin{array}{l}\text { Trichoderma } \\
\text { virens }\end{array}$ \\
\hline \multicolumn{5}{|l|}{ Potato strains } \\
\hline$P C C_{1}$ & 0.00 & 0.88 & 0.00 & 1.08 \\
\hline $\mathrm{PCC}_{2}$ & 0.00 & 1.01 & 0.00 & 0.90 \\
\hline $\mathrm{PCC}_{3}$ & 0.00 & 0.71 & 0.75 & 0.73 \\
\hline $\mathrm{PCC}_{4}$ & 0.00 & 0.87 & 0.70 & 0.83 \\
\hline \multicolumn{5}{|c|}{ Sweet potato strain } \\
\hline $\mathrm{PCC}_{5}$ & 0.00 & 0.73 & 0.75 & 0.78 \\
\hline \multicolumn{5}{|c|}{ Cucumber strains } \\
\hline$P C C_{6}$ & 0.00 & 0.00 & 0.00 & 0.00 \\
\hline $\mathrm{PCC}_{7}$ & 0.00 & 0.73 & 0.78 & 0.70 \\
\hline $\mathrm{PCC}_{8}$ & 0.00 & 1.08 & 0.81 & 1.10 \\
\hline \multicolumn{5}{|l|}{ Carrot strains } \\
\hline $\mathrm{PCC}_{9}$ & 0.00 & 0.00 & 0.00 & 0.70 \\
\hline$P C C_{10}$ & 0.00 & 0.00 & 0.00 & 0.00 \\
\hline$P C C_{11}$ & 0.00 & 0.93 & 0.88 & 0.95 \\
\hline \multicolumn{5}{|c|}{ Eggplants strains } \\
\hline$P C C_{12}$ & 0.00 & 0.00 & 0.70 & 0.00 \\
\hline$P C C_{13}$ & 0.00 & 0.70 & 0.00 & 0.00 \\
\hline \multicolumn{5}{|c|}{ Chili fruits strains } \\
\hline$P_{C C} 14$ & 0.00 & 0.70 & 0.85 & 0.80 \\
\hline$P C C_{15}$ & 0.00 & 0.66 & 0.93 & 0.78 \\
\hline Total mean & 0.60 & 0.48 & 0.62 & \\
\hline
\end{tabular}

L.S.D. 0.05 Strains $(I)=0.04$ Bioagent $(B)=0.081 \times B=0.15$

inoculated potato slices, while $P c c_{3}$ strain produced small active rot symptom. Bacillus subtilis when applied at the same time or $2 \mathrm{~h}$ after the pathogen inoculation strains $P C_{3}, P c c_{4}$ and $P c c_{5}$ could produce highly active rot symptoms. Results revealed that when $B$. pumilus applied at $2 \mathrm{~h}$ before the pathogen inoculation, no soft rot symptoms were occurred on inoculated potato slices with $P c c_{3}$ and $P c c_{4}$ strains, while highly active rot symptoms were produced by strain $P_{c c_{5}}$. Bacillus pumilus when applied at the same time of soft rot pathogen inoculation, strains $P C_{3}$ and $P c c_{5}$ could produce highly active rot symptoms, while no soft rot symptoms were recorded with $P \mathrm{Cc}_{4}$ strain. Strains $P c_{4}$ and $P c c_{5}$ produced highly active rot symptoms, while no soft rot symptoms were recorded with strain $P c_{3}$, when $B$. pumilus applied after $2 \mathrm{~h}$ the pathogen inoculation. Results showed that no rotting symptoms were recorded by $P c c_{3}$ and $P c c_{4}$ on inoculated potato slices when $B$. megaterium applied $2 \mathrm{~h}$ before or at the same time of pathogen inoculation, while strain $\mathrm{Pcc}_{5}$ produced highly active rot symptoms. Bacillus megaterium when applied after $2 \mathrm{~h}$ of pathogen inoculation; strains $P c c_{3}$ and $P c c_{5}$ could produce highly active rot symptoms, while no soft rotting was recorded with $P c c_{4}$. Pseudomonas fluorescens, when applied $2 \mathrm{~h}$ before pathogen inoculation, could prevent the soft rot symptoms with all applied soft rot strains as well as when it applied at the same time of pathogen inoculation, except $P c c_{5}$ strain which could produce highly active rot symptoms. Pseudomonas fluorescens when applied after $2 \mathrm{~h}$ of pathogen inoculation; no soft rotting, symptoms were recorded with strains $P c c_{3}, P c c_{4}$ and $P c c_{5}$, respectively (Table 4).

Results revealed that $T$. harzianum when applied $2 \mathrm{~h}$ before pathogen inoculation, no soft rotting was recorded with $P_{c c_{4}}$ and $P c c_{5}$ strains on inoculated potato slices, while $P c c_{3}$ could produce highly active rot symptoms. Trichoderma harzianum also when applied at the same time or $2 \mathrm{~h}$ after pathogen inoculation, $P c c_{3}$ and $P_{c c} c_{4}$ could not produce any soft rot symptoms, while $P c c_{5}$ could produce highly active rot symptoms. Trichoderma viride when applied $2 \mathrm{~h}$ before pathogen inoculation strains $P c_{3}$ and $P c c_{5}$ could produce highly active rot symptoms, while no rotting was recorded with strain $P_{c c}$. Results showed that no soften symptoms were recorded using $T$. viride when applied at the same time or $2 \mathrm{~h}$ after the pathogen inoculation with tested soft rot bacteria, except $P c c_{3}$ and $P c c_{5}$ which could produce highly active rot symptom, respectively. Trichoderma virens when applied $2 \mathrm{~h}$ before the pathogen inoculation with strains $P c_{3}$ or $P c c_{4}$ could produce highly active rot symptoms, while no soft rotting was recorded with strain $P c c_{5}$. T. virens when applied at the same time or $2 \mathrm{~h}$ after of the pathogen inoculation where no soft rotting was recorded, except $P c_{3}$ and $P c_{5}$ which could produce highly and small active rot symptom at above periods, respectively (Table 4).

\section{b. Whole potato tubers method}

Results revealed that the cultural filtrates of B. subtilis, B. pumilus, B. megaterium, P. fluorescens, T. harzianum, $T$. viride and $T$. virens could differently protect the whole potato tubers against soft rot disease incidence, under artificially infection in storage, as shown in Table 5. The cultural filtrates of bacterial agents and fungal agents could reduce the soft rot disease incidence in the ranges of $4.5-12.5 \%$ and $3.2-21.9 \%$, compared to the ranges of $5.5-83.0 \%$ in the untreated control during three months of storage, respectively. Results revealed that B. pumilus could protect potato tubers against the soft rot disease during storage period. On the other hand, B. subtilis could protect the potato tubers until the 9th week, and then, the soft rot disease incidence reached to $6.0 \%$ at the 10th week, followed by $12.2 \%$ at the two last weeks of storage. Application of B. megaterium could protect 
Table 4 Inhibitory activity of the crude cultural filtrates of biocontrol agents against Pectobacterium carotovorum subsp. Carotovorum strains, when artificially inoculated on potato tuber slices, in vivo tests

\begin{tabular}{|c|c|c|c|c|c|c|c|c|c|}
\hline \multirow[t]{3}{*}{ Biocontrol agents } & \multicolumn{9}{|c|}{ Soft rot symptoms } \\
\hline & \multicolumn{3}{|c|}{$2 \mathrm{~h}$. before inoculation } & \multicolumn{3}{|c|}{ At the same time } & \multicolumn{3}{|c|}{$2 \mathrm{~h}$. after inoculation } \\
\hline & $\mathrm{PCC}_{3}$ & $\mathrm{PcC}_{4}$ & $\mathrm{PCC}_{5}$ & $\mathrm{PCC}_{3}$ & $\mathrm{PcC}_{4}$ & $\mathrm{PCC}_{5}$ & $\mathrm{Pcc}_{3}$ & $\mathrm{Pcc}_{4}$ & $\mathrm{Pcc}_{5}$ \\
\hline \multicolumn{10}{|l|}{ Bacterial agents } \\
\hline Bacillus subtilis & $++^{*}$ & +++ & +++ & +++ & +++ & +++ & +++ & +++ & +++ \\
\hline Bacillus pumilus & - & - & +++ & +++ & - & +++ & - & +++ & +++ \\
\hline Bacillus megaterium & - & - & +++ & - & - & +++ & +++ & - & +++ \\
\hline Pseudomonas fluorescens & - & - & - & - & - & +++ & - & ++ & +++ \\
\hline \multicolumn{10}{|l|}{ Fungal agents } \\
\hline Trichoderma harzianum & +++ & - & - & - & - & +++ & - & - & +++ \\
\hline Trichoderma viride & +++ & - & +++ & +++ & - & - & - & - & +++ \\
\hline Trichoderma virens & +++ & +++ & - & +++ & - & - & - & - & ++ \\
\hline \multicolumn{10}{|l|}{ Pathogen only } \\
\hline P.c. subsp. carotovorum only & +++ & +++ & +++ & +++ & +++ & +++ & +++ & +++ & +++ \\
\hline \multicolumn{10}{|l|}{ Untreated control } \\
\hline Water only & - & - & - & - & - & - & - & - & - \\
\hline
\end{tabular}

*-No rotting

+ Restricted $\operatorname{rot}<1 \mathrm{~cm}$

++ Small active rot $1-2 \mathrm{~cm}$

+++ Highly active $\operatorname{rot}>2 \mathrm{~cm}$

Table 5 Inhibitory activity of biocontrol agents against incidence of bacterial soft rot disease on potato tubers when artificially inoculated in vivo tests

\begin{tabular}{|c|c|c|c|c|c|c|c|c|c|c|c|c|}
\hline \multirow[t]{2}{*}{ Biocontrol agents } & \multicolumn{12}{|c|}{ Soft rot incidence (weight losses\%) at weeks } \\
\hline & 1 & 2 & 3 & 4 & 5 & 6 & 7 & 8 & 9 & 10 & 11 & 12 \\
\hline \multicolumn{13}{|l|}{ Bacterial agents } \\
\hline Bacillus subtilis & 0.0 & 0.0 & 0.0 & 0.0 & 0.0 & 0.0 & 0.0 & 0.0 & 0.0 & 6.0 & 12.2 & 12.2 \\
\hline Bacillus pumilus & 0.0 & 0.0 & 0.0 & 0.0 & 0.0 & 0.0 & 0.0 & 0.0 & 0.0 & 0.0 & 0.0 & 0.0 \\
\hline Bacillus megaterium & 0.0 & 0.0 & 0.0 & 0.0 & 0.0 & 0.0 & 0.0 & 0.0 & 5.1 & 5.1 & 12.5 & 12.5 \\
\hline Pseudomonas fluorescens & 0.0 & 0.0 & 0.0 & 0.0 & 0.0 & 0.0 & 0.0 & 0.0 & 0.0 & 0.0 & 4.5 & 4.5 \\
\hline \multicolumn{13}{|l|}{ Fungal agents } \\
\hline Trichoderma harzianum & 0.0 & 0.0 & 0.0 & 0.0 & 0.0 & 0.0 & 0.0 & 0.0 & 0.0 & 0.0 & 8.0 & 21.9 \\
\hline Trichoderma viride & 0.0 & 0.0 & 0.0 & 0.0 & 0.0 & 0.0 & 0.0 & 3.2 & 3.2 & 3.2 & 3.2 & 3.2 \\
\hline Trichoderma virens & 0.0 & 0.0 & 0.0 & 0.0 & 0.0 & 0.0 & 0.0 & 3.2 & 3.2 & 3.2 & 3.2 & 3.2 \\
\hline \multicolumn{13}{|l|}{ Pathogen only } \\
\hline P. c. subsp. carotovorum only & 5.5 & 16.4 & 43.7 & 50.7 & 83.0 & 83.0 & 83.0 & 83.0 & 83.0 & 83.0 & 83.0 & 83.0 \\
\hline
\end{tabular}

L.S.D. 0.05 Bioagent $(B)=1.4$ weeks $(W)=1.7 \mathrm{~B} \times \mathrm{W}=4.7$

potato tubers to the 8 th week, and the disease incidence ranged from 5.1 to $12.5 \%$ at the four last weeks of storage. Pseudomonas fluorescens could protect the potato tubers until the $10^{\text {th }}$ week, and then, the disease incidence was $4.5 \%$ at the two last weeks of storage (Table 4). Application of T. harzianum could protect the potato tubers until the 10th week of storage, and then, the disease incidence ranged from 8.0 to $21.9 \%$ at the two last weeks of storage, respectively. Both $T$. viride and $T$. virens could protect the potato tubers until the $7^{\text {th }}$ week of storage and then the disease incidence was 3.2\% at the four weeks of storage (Table 4).

\section{Discussion}

The bacterial soft rot disease, caused by $P$. carotovorum subsp. carotovorum, causes severe losses in many vegetables in fields, storages and transit, where the losses ranged from 15 to $30 \%$ in harvested vegetables and reached $60 \%$ 
in stored potatoes (Abd-El-Khair 2004). Application of chemical bactericides for controlling bacterial plant diseases is a common practice as well as they cause hazardous effects to human, animals and environment. Application of biological control agents may replace the chemicals and considered to be more effective and environmentally safe (Abd-El-Khair, and Seif El-Nasr 2012; Beric et al. 2012; Abdel-Gaied et al. 2020). Therefore, in this work we applied the cultural filtrates of B. subtilis, $B$. pumilus, B. megaterium, P. fluorescens, T. harzianum, $T$. viride and $T$. virens for testing their antagonistic activity against $P$. carotovorum subsp. carotovorum (15 strains) which isolated from some vegetables showing typical soft rot symptoms, viz. potato tubers, sweet potato roots, cucumber fruits, carrot roots, eggplant fruits and chili fruits (Mikhail et al. 2019).

Our results in vitro showed that the tested biocontrol agents had variable antagonistic effects against $P$. carotovorum subsp. carotovorum isolates, where $B$. pumilus had more antagonistic effect against soft rot bacteria, than $B$. subtilis, B. megaterium and P. fluorescens. On the other hand, T.virens showed more antagonistic effect, than T. harzianum, T. viride. Similar results revealed that $B$. subtilis (Rashid et al. 2013) and P. fluorescens (Sandipan et al. 2015; El-Hendawy and Abo-Elyousr 2016) had the stronger antagonistic activity against $E$. carotovora subsp. carotovora in vitro tests. Bacillus subtilis showed the maximum inhibition zones diameter, followed by $P$. fluorescens, $T$. harzianum and $T$. viride against $E$. carotovora subsp. carotovora in vitro tests as recorded by Makhlouf and Abdeen (2014) and El-Naggar et al. (2016).

Our results of in vivo tests showed that the cultural filtrate of $P$. fluorescens was more effective in reducing the soft rot disease incidence on soft rot pathogen-inoculated potato slices, when applied $2 \mathrm{~h}$ before or at the same time of pathogen inoculation, followed by $B$. megaterium and B. pumilus, while cultural filtrate of $B$. subtilis was not effective. On the other hand, T. virens was more effective in reducing the disease incidence, when applied at same time or $2 \mathrm{~h}$ after of pathogen inoculation, than T. viride and $T$. harzianum. It is cleared that the bacterial biocontrol agents may a preventive effect, while Trichoderma maybe have a curative effect against soft rot pathogen. These results are in agreement with those recorded by $\mathrm{Xu}$ and Gross (1986). They reported that the fluorescent Pseudomonas may play role in suppressing the Erwinia soft rot by producing the siderophores or antibiotics. Hajhamed et al. (2007) also revealed that P. fluorescens and B.subtilis, when applied after, before or at the same time of inoculation, could control soft rot disease in potato. B.subtilis was the best biocontrol agent against soft rot bacterium after $48 \mathrm{~h}$ of incubation in vitro tests (Rashid et al. 2013). El-Naggar et al. (2016) reported that
B. subtilis, P. fluorescens, T. harzianum and T. viride protected the potato slices against the soft rot development and reduced the amount of tissue maceration in vivo tests.

Storage results showed that the tested biocontrol agents could protect the of potato whole tubers against soft rot disease. Bacillus pumilus showed the highest protective, followed by $P$. fluorescens, B. subtilis and $B$. megaterium. Trichoderma harzianum revealed a higher antagonistic effect, than $T$. viride and $T$. virens. These results are in agreement with those recorded by Rahman et al. (2012). They mentioned that Bacillus species showed the stronger antagonistic effect against E. carotovora subsp. carotovora in vitro tests, where it could reduce the soft rot infection until 22-week storage potatoes. B. subtilis; P. fluorescens and T. viride combined with chitosans (CS) had the stronger antagonistic activity against the growth of E. carotovora subsp. carotovora in vitro and in storage. The stronger antagonistic activity against $E$. carotovora subsp. carotovora was obtained by CS5\% treatment with T. viride, P. fluorescens and B. subtilis, respectively. All treatments reduced the soft rot infection until 20-week storage (Makhlouf and Abdeen 2014). El-Hendawy and Abo-Elyousr (2016) reported that $B$. subtilis or P.fluorescens could suppress the growth of Pectobacterium atrosepticum growth individually or in combination in vitro, under greenhouse and field conditions, where the combination had a beneficial effect.

\section{Conclusion}

It can be concluded that fungal biocontrol agents, i.e., $T$. harzianum, T. viride and T.virens, and bacterial biocontrol agents, i.e. B. subtilis, B. pumilus, B. megaterium and $P$. fluorescens could control the most of P.carotovorum subsp. carotovorum isolates causing the soft rot disease varied in vitro and in vivo tests. Results revealed that the tested biocontrol agents were varied in their antagonistic activity against bacterial soft rot isolates in vitro tests, where the biocontrol cultural filtrates could not reduce the bacterial growth of some pathogenic isolates. In vivo tests, $T$. viride and $T$. virens were highly effective in reducing soft rot symptoms on inoculated potato tuber slices, when applied at the same time or $2 \mathrm{~h}$ before pathogen inoculation, while $B$. megaterium and T. harzianum were high effective when applied at the same time or $2 \mathrm{~h}$ after pathogen inoculation. In whole potato tubers technique, B.pumilus highly protected the stored potato tuber, than P. fluoresces, T. harzianum, B. subtilis, T. viride, T. virens and B. megaterium, respectively. It is clear that the application of Trichoderma spp. or bacterial species could play an important role in controlling bacterial soft rot disease in vegetables. 


\section{Abbreviations}

T.: Trichoderma; B.: Bacillus; P.: Pseudomonas and Pectobacterium.

\section{Acknowledgements}

Not applicable.

\section{Authors' contributions}

TGA prepared the materials and carried out the experiment in the open field MSM performed supervision and reviewing the manuscript; AIA was involved in data analysis and visualization; HIS wrote the manuscript; HAE was involved in suggesting the problem and helped in writing the manuscript. All authors revised, read and approved the final manuscript.

\section{Funding}

There is no funding.

\section{Availability of data and materials}

The tested biocontrol agents, plant species and bacterial soft rot pathogens are available in Egyptian environment and were identified in the laboratory.

\section{Ethics approval and consent to participate}

Not applicable.

\section{Consent for publication}

Not applicable.

\section{Competing interests}

The authors declare that they have no competing interests.

\section{Author details}

1 Plant Pathology Department, National Research Centre, Dokki, Giza, Egypt.

2 Plant Pathology Department, Faculty of Agriculture, Cairo University, Giza, Egypt.

Received: 1 November 2020 Accepted: 13 January 2021

Published online: 05 February 2021

\section{References}

Abdel-Gaied TG, Mikhai MS, Abdel-Alim Al, Seif El-Nasr HI, Abd El-Khair $H$ (2020) Field application of bio-control agents and aqueous plant extracts for controlling bacterial soft rot and enhancement yield quality of Solanum tuberosum L. cv. Diamond. Bull Natl Res Centre 44:82

Abd-El-Khair H (2004) Variation and control of Erwinia carotovora subsp. carotovora isolates, the causal agent of potato soft rot disease. Ann Agric Sci 49(1):377-388

Abd-El-Khair H, Haggag KHE (2007) Application of some bactericides and bioagents for controlling the soft rot disease in potato. Res J Agric Biol Sci 3(5):463-473

Abd-El-Khair H, Seif El-Nasr HI (2012) Applications of Bacillus subtilis and Trichoderma spp. for controlling the potato brown rot in field. Arch Phytopathol Plant Protect 45(1):1-15

Alabouvette C, Olivain C, Steinberg C (2006) Biological control of plant diseases: the European situation. Eur J Plant Pathol 114:329-341

Algeblawi A, Adam F (2013) Biological control of Erwinia carotovora subsp. carotovora by Pseudomonas fluorescens, Bacillus subtilis and Bacillus thuringiensis. Int J Chem Environ Biol Sci 1(5):771

Bartz JA (1999) Suppression of bacterial soft rot in potato tubers by application of ksugamycin. Am J Potato Res 76(3):127-136

Beric T, Kojic M, Stankovic S, Topisirovic L, Degrassi G, Myers M, Venturi V, Fira D (2012) Antimicrobial activity of Bacillus sp. natural isolates and their potential use in the biocontrol of phytopathogenic bacteria. Food Technol Biotechnol 50(1):25-31

Bhat KA, Masood SD, Bhat NA, Bhat MA, Razvi SM, Mir MR, Akhter S, Wani N, Habib M (2010) Current status of post-harvest soft rot in vegetables: a review. Asian J Plant Sci 9(4):200-208

El-Hendawy HH, Abo-Elyousr KAM (2016) Combination of different antagonistic bacteria to control of potato blackleg disease caused by Pectobacterium atrosepticum under greenhouse and field conditions. Int J Phytopathol 5(1):35-43
El-Naggar MA, Abouleid HZ, Abd-El-Kareem F, El-Deeb HM, Elshahawy IE (2016) Soft rot disease management of imported potato designed for cultivation during early summery season in Egypt. Res J Pharmaceut Biol Chem Sci 7(1):1349-1359

Ghods-Alavi BS, Ahmadzadeh M, Behhoudi K, Jamali S (2012) Biocontrol of rhizome soft rot (Pectobacterium carotovorum) on Valerian by Pseudomonas spp. under in vitro and greenhouse conditions. J Agric Technol 8(6):1913-1923

Hajhamed AA, Abd El-Sayed WM, Abou El-Yazid A, Abd-El-Ghaffar NY (2007) Suppression of bacterial soft rot disease of potato. Egypt J Phytopathol 35(2):69-80

Idowu OO, Olawole OI, Idumu OO, Salami AO (2016) Bio-control effect of Trichoderma asperellum (Samuels) Lieckf and Glomus intraradices Schenk on okra seedlings infected with Pythium aphanidermatum (Edson) Fitzp and Erwinia carotovora (Jones). Am J Exp Agric 10(4):1-12 Issazadeh K, Rad SK, Zarrabi S, Rahimibashar MR (2012) Antagonism of Bacillus species against Xanthomonas campestris pv. campestris and Pectobacterium carotovorum subsp. carotovorum. African Journal of Microbiology Research 6(7):1615-1620

Jones AL, McManus PS, Chiou CS (1996) Epidemiology and genetic diversity of streptomycin resistance in E. amylovora in Michigan. Acta Hort 338:333-340

Makhlouf AH, Abdeen R (2014) Investigation on the effect of chemical and biological control of bacterial soft rot disease of potato in storage. $J$ Biol Agric Healthcare 4(10):31-44

Mikhail MS, Abdel-Alim Al, Abd-El-Khair H, Abdel-Gaied TG, Mohamed SA (2019) Host range and total cellular protein fingerprint of soft rot Erwinia isolated from some vegetables in Egypt. Plant Arch 19(1):295-306

Mills AAS, Platt HWB, Hurta RAR (2006) Sensitivity of Erwinia spp. to salt compounds in vitro and their effect on the development of soft rot in potato tubers in storage. Post-Harvest Biol Technol 41:208-214

Moh AA, Massart S, Jijakli MH, Lepoivre P (2012) Models to predict the combined effects of temperature and relative humidity on Pectobacterium atrosepticum and Pectobacterium carotovorum subsp. carotovorum population density and soft rot disease development at the surface of wounded potato tubers. J Plant Pathol 94(1):181-191

Opara EU, Asuquo AA (2016) An overview of characterization and identification of soft rot bacterium Erwinia in some vegetable crops. Greener J Biol Sci 6(3):46-55

Péromblon MCM (2002) Potato diseases caused by soft rot erwinias: an overview of pathogenesis. Plant Pathol 51:1-12

Rahman MM, Ali ME, Khan AA, Uddin MK, Hashim U, Abd Hamid SB (2012) Isolation, characterization and identification of biological control agent for potato soft rot in Bangladesh. Sci World J 6:72393. https://doi. org/10.1100/2012

Rashid M, Chowdhury MSM, Sultana N (2013) In vitro screening of some chemicals and biocontrol agents against Erwinia carotovora subsp. carotovora the causal agent of soft rot of potato (Solanum tuborosum). Agricultrists 11(2):1-9

Sandipan PB, Chaudhary RF, Shanadre CM, Rathod NK (2015) Appraisal of diverse bioagents against soft rot bacteria of potato (Solanum tuberosum L.) caused by Erwinia carotovra subsp carotovora under in vitro test. Eur J Pharmaceut Med Res 2(4):495-500

de Silva MS, Carvalho FCQ, de Silva JR, Lins SRO, de Oliveira SMA (2014) Use of antagonists and alternative products to manage post-harvest soft rot in pepper. Revista Ciência Agronômica 45(4):718-725

Snedecor GW, Cochran WG (1980) Statistical methods, 5th edn. lowa State University Press, Ames, IA

Sowmya DS, Rao MS, Kumar RM, Gavaskar J, Priti K (2012) Bio-management of Meloidogyne incognita and Erwinia carotovora in Carrot (Daucus carota L.) using Pseudomona putida and Paecilomyces lilacinus. Nematol Med 40:189-194

Thornberry HH (1950) A paper-disk method for the quantitative evaluation of fungicides and bactericides. Phytopathology 40:419-429

Vanneste JL (2000) Fire blight The disease and causative agent Erwinia amylovora. CABI Publications, New York, pp 1-370

Wulff EG, Van Vuurde JWL, Hockenhull J (2003) The ability of the biological control agent Bacillus subtilis, strain BB, to colonize vegetable brassicas endophytically following seed inoculation. Plant Soil 255:463-474 
Xu GW, Gross DC (1986) Selection of fluorescent Pseudomonas antagonistic to Erwinia carotovora and suppressive of potato seed piece decay. Phytopathology 76:414-422

\section{Publisher's Note}

Springer Nature remains neutral with regard to jurisdictional claims in published maps and institutional affiliations.
Submit your manuscript to a SpringerOpen ${ }^{\circ}$ journal and benefit from:

- Convenient online submission

- Rigorous peer review

- Open access: articles freely available online

- High visibility within the field

- Retaining the copyright to your article

Submit your next manuscript at $\boldsymbol{\nabla}$ springeropen.com 